\title{
PENGARUH KEPUASAN KERJA DAN KOMITMEN ORGANISASI \\ TERHADAP KINERJA KARYAWAN (STUDI KASUS PEKERJA PRODUKSI AIR MINERAL AMPO BAGIAN CUP DI CV LISA JAYA MANDIRI FOOD)
}

\author{
ALIFIAN NUGRAHA* \\ ISTIQOMAH \\ Program Studi Ilmu Administrasi Niaga \\ Sekolah Tinggi Ilmu Administrasi Pembangunan Jember \\ *Email: alifian@stiapembangunanjember.ac.id
}

\begin{abstract}
ABSTRAK
Manajeman Sumber Daya Manusia (MSDM) berfungsi untuk meningkatkan kinerja karyawan. Peningkatan kinerja karyawan salah satunya bisa dilihat dari tingkat kepuasan kerja dan komitmen organisasi. tingginya kepuasan kerja dan komitmen organisasi diharapkan bisa meningkatkan kinerja karyawan. Penelitian ini bertujuan untuk menganalisis pengaruh antara variabel kepuasan kerja dan komitmen orgaisasi baik secara simultan dan pengaruh kepuasan kerja dan komitmen organisasi secara parsial terhadap kinerja. Penelitian ini menggunakan pendekatan kuantitatif dan tipe penelitian yang digunakan adalah penelitian Eksplanatory Research (penelitian penjelasan) dengan menggunakan kuesioner. Penelitian ini dilakukan di CV Lisa Jaya Mandiri Food di Desa Dukuh Mencek Kecamatan Sukorambi Kabupaten Jember. Populasi yang digunakan dalam penelitian ini adalah karyawan CV Lisa Jaya Mandiri Food bagian cup yang berjumlah 35 orang. Teknik pengambilan sampel dengan menggunakan metode sampel jenuh dengan menjadikan seluruh anggota populasi sebagai sampel. Pada penelitian ini analisis data yang digunakan yaitu analisis deskriptif dan analisis inferensial yang terdiri dari

uji asumsi klasik dan analisis regresi linier berganda dengan bantuan aplikasi IBM SPSS 22. Hasil penelitian menunjukkan bahwa secara simultan kepuasan kerja dan komitmen organisasi berpengaruh signifikan terhadap kinerja karyawan. Secara parsial kepuasan kerja dan komitmen organisasi berpengaruh signifikan terhadap kinerja karyawan.
\end{abstract}

Kata Kunci: Kepuasan Kerja, Komitmen Organisasi, Kinerja Karyawan 


\section{PENDAHULUAN}

Setiap perusahaan di Indonesia dalam perkembangan bisnis harapannya adalah menuju ke arah yang lebih baik agar dapat bersaing dalam dunia bisnis yang semakin kompleks. Pada dasarnya perusahaan harus memiliki strategi bisnis yang tepat supaya dapat bersaing dan bertahan dalam persaingan bisnis. Salah satu strategi perusahaan adalah mengembangkan teknologi dan strategi inovasi pengembangan mutu sumber daya manusia.

Keberhasilan perusahaan dalam mencapai tujuan tidak lepas dari peran sumber daya manusia dalam menjalankan operasional perusahaan, karena sumber daya manusia yang ada dalam perusahaan merupakan faktor penggerak perusahaan.

Dalam pengelolaan sumber daya manusia, perusahaan harus memperhatikan kinerja karyawan agar dapat bekerja maksimal. Perusahaan dalam pelaksaan kegiatan bisnisnya berupaya melakukan peningkatan kinerja karyawan dengan berbagai cara. Karyawan "didorong untuk bekerja maksimal demi tercapainya tujuan perusahaan. Upaya yang dilakukan oleh perusahaan untuk meningkatkan kinerja karyawan adalah dengan memberikan bonus dan penghargaan kepada karyawan yang memiliki nilai kerja yang baik."

Kepuasan kinerja karyawan salah satu aspek penting yang harus diperhatikan oleh perusahaan. Selain itu kepuasan kerja merupakan indikator yang penting untuk mendapatkan hasil kerja yang optimal. Kepuasan kerja dapat diartikan perasaan senang atau tidak senang karyawan kepada pekerjaan yang mereka lakukan.

Komitmen organisasi merupakan loyalitas yang dimiliki seorang karyawan terhadap perusahaan dimana karyawan itu bekerja. Komitmen yang dimiliki karyawan juga bisa dipandang sebagai suatu keadaan dimana seorang karyawan memihak pada suatu organisasi dan tujuannya, serta ingin memelihara keanggotaan dalam organisasi tersebut. Komitmen yang tinggi akan membuat karyawan loyalitas kepada perusahaan. dalam 
bentuk tenaga ataupun pikiran demi kemajuan dan tercapainya tujuan.

CV. Lisa Jaya Mandiri Food adalah perusahaan yang didirikan pada tahun 2005 oleh Wasili Fadlah dan istrinya bernama Lisa. Perusahaan ini merupakan perusahaan yang menjual beberapa produk seperti kopi, kerupuk, minyak goreng, bumbu penyedap, dan air mineral Ampo. Maka disini diperlukan pekerja yang lebih banyak, kegiatan operasional lebih panjang, dan pengawasan yang lebih ketat. Di bagian produksi semakin mengalami perubahan mengikuti trend masa kini, khususnya dalam spesifikasi untuk menjadi pekerja bagian produksi.

Berdasarkan hasil observasi langsung kepada pekerja bagian produksi, setiap ada masa training (tiga bulan), ada saja pekerja yang memutuskan berhenti kerja sebelum masa training habis. Hal ini karena pekerja merasa bahwa harapan yang dibawa sebelum menjadi bagian dari perusahaan ternyata setelah mereka merasakan langsung tidak sesuai dengan harapan. Pekerja masih belum bisa menerima timbal balik dari perusahaan. Seperti halnya mereka yang merupakan pekerja baru akan mendapatkan upah permulaan. Informasi yang di dapat dari hasil observasi langsung kepada pekerja, mereka yang berhenti bekerja di dominasi oleh pekerja bagian cup. Sebenarnya, CV. Lisa Jaya Mandiri Food memberikan upah layak yang dapat diterima oleh pekerja, namun didasarkan pada produktivitas dari kelompok kerja.

Pekerja bagian produksi didominasi oleh pemuda yang baru lulus dari jenjang SMA/SMK. Pekerjaan yang monoton dan upah yang kurang memuaskan membuat mereka terdorong untuk mencari pengalaman baru. Hal ini sesuai dengan semangat pemuda yang selalu ingin mencoba suatu tantangan. Di tambah lagi pengiriman produk air mineral tidak terstruktur. Jika stock bahan baku untuk kemasan habis maka pekerja produksi air mineral akan diliburkan. Maka hal ini juga menambah kurangnya kepuasan kerja dari para pekerja bagian cup. Keinginan untuk tetap tinggal di perusahaan sudah mulai turun, di tambah lagi pekerja 
tidak mampu lagi untuk memenuhi target perusahaan ke depan, maka pekerja akan berfikir untuk keluar dan mencari pekerjaan yang lebih baik.

Berdasarkan hasil observasi langsung kepada bagian personalia

\section{TINJAUAN PUSTAKA}

\subsection{Manajemen Sumber Daya} Manusia

Manajemen sumber daya manusia adalah suatu perencanaan formal dalam perusahaan yang bertujuan untuk memastikan seberapa efektif dan efisienkah kemampuan dari sumber daya manusia yang ada agar dapat mencapai tujuan perusahaan (Mathis \& Jackson, 2006:5). Manajemen sumber daya manusia adalah pengelolaan sumber daya manusia sebagai sumber daya atau aset yang utama, melalui penerapan fungsi manajemen maupun fungsi operasional sehingga tujuan organisasi yang telah ditetapkan dapat tercapai dengan baik (Sinambela, 2018).

Dari beberapa pengertian atau definisi yang ada, dapat disimpulkan dan pekerja di bagian produksi, maka peneliti tertarik untuk melakukan penelitian dengan judul "Pengaruh Kepuasan Kerja dan Komitmen Organisasi Terhadap Kinerja Karyawan".

bahwa Sumber Daya Manusia (SDM) terdiri dari daya fikir dan daya fisik setiap manusia. Tegasnya kemampuan setiap manusia ditentukan oleh daya fikir dan daya fisiknya. SDM menjadi unsur utama dalam setiap aktivitas yang dilakukan. Peralatan yang handal atau canggih tanpa peran aktif SDM, tidak berarti apa-apa.

\subsection{Kinerja Karyawan}

Definisi kinerja menurut Bangun (2012) merupakan suatu hasil kerja yang telah diperoleh individu berdasar pada syarat pekerjaan tersebut. Sedangkan menurut Dharma (2003) yakni ada beberapa situasi yang memerlukan standar yang sama bagi semua karyawan yang melakukan pekerjaan serupa. Kinerja yang baik dapat 
ditentukan atau diukur menggunakan indikator-indikator kinerja. Dharma (2003:355) mengemukakan standar pengukuran kinerja diantaranya sebagai berikut:

1. Kuantitas. Pengukuran kuantitatif melibatkan perhitungan keluaran dari proses atau pelaksanaan kegiatan. Ini berkaitan dengan jumlah keluaran yang dihasilkan.

2. Kualitas. Pengukuran keluaran kualitatif mencerminkan pengukuran tingkat kepuasan, yaitu seberapa baik penyelesaiannya. Ini berkaitan dengan bentuk keluaran.

3. Ketepatan. Pengukuran ketepatan waktu merupakan jenis khusus dari pengukuran kuantitatif yang menentukan ketepatan waktu penyelesaian suatu kegiatan.

\subsection{Kepuasan Kerja}

Kuswadi (2004) berpendapat bahwa kepuasan karyawan merupakan ukuran sampai seberapa jauh perusahaan dapat memenuhi harapan karyawannya yang berkaitan dengan berbagai aspek dalam pekerjaan dan jabatan. Menurut Robbins (2008), Kepuasan kerja sebagai suatu sikap umum seseorang individu terhadap pekerjannya dimana dalam pekerjaanya tersebut seseorang dituntut untuk berinteraksi dengan rekan sekerjanya dan atasan, mengikuti aturan dan kebijaksanaan organisasi serta memenuhi standar kinerja. Menurut Hackman dan Oldham dalam Robbins (2008), indikator kepuasan kerja dapat dilihat dari beberapa faktor yaitu:

1. Taks Indenty

2. Autonomy

3. Feed Back From The Job In Self

\subsection{Komitmen Organisasi}

Komitmen organisasi menunjukkan loyalitas karyawan terhadap suatu organisasi atau perusahaan. Loyalitas tersebut dapat berupa kemauan untuk bekerja lebih keras demi tercapainya tujuan perusahaan. Menurut Robbins (2008), komitmen karyawan merupakan usaha mendefinisikan dan melibatkan diri dalam organisasi dan tidak ada keinginan meninggalkannya. 
Allen dan Meyer (1984) dalam Robbins (2012:99), mengemukakan bahwa terdapat tiga dimensi terpisah komitmen organisasional, yaitu:

1. Affective commitment adalah keinginan untuk bekerja pada perusahaan karena sepakat terhadap tujuan organisasi dan ada keinginan untuk menjalankannya.

2. Continuance commitment adalah keinginan untuk tetap bekerja pada perusahaan karena tidak ingin kehilangan sesuatu yang terkait dengan pekerjaannya.

3. Normative commitment adalah keinginan untuk bekerja pada perusahaan karena kewajiban (obligation) untuk bertahan dalam organisasi.

\subsection{Hubungan Antar Variabel}

Hubungan Kepuasan Kerja dan

\section{Komitmen Organisasi dengan}

\section{Kinerja Karyawan}

Hal yang dapat mendukung kinerja karyawan tersebut adalah kepuasan kerja dan komitmen organisasional. Dengan kepuasan kerja yang yang terpenuhi dan disertai dengan komitmen organisasional yang tinggi akan meningkatkan kinerja karyawan. Hasil penelitian yang dilakukan Mardianai dan Dewi (2015); Novita, et al (2016) ; dan Jazuli, et al (2017) menunjukkan bahwa kepuasan kerja dan komitmen organisasi secara simultan berpengaruh terhadap kinerja karyawan. Berdasarkan uraian tersebut jelas bahwasannya kepuasan kerja dan komitmen organisasi berpengaruh terhadap kinerja karyawan.

\section{Hubungan Kepuasan Kerja dengan Kinerja Karyawan}

Kepuasan kerja memiiki peran untuk mencapai produktivitas dan kualitas standar yang lebih baik, menghindari terjadinya kemungkinan membangun kekuatan kerja yang lebih stabil, seta penggunaan sumber daya manusia yang lebih efisien (Dessler,2009). Hasil penelitian yang dilakukan oleh Mardianai dan Dewi (2015); Novita, et al (2016) ; dan Jazuli, et al (2017), menunjukkan bahwa kepuasan kerja berpengaruh terhadap kinerja karyawan. 


\section{Hubungan Komitmen Kerja dengan Kinerja Karyawan}

Komitmen mengekspresikan baik dalam pikiran maupun tindakan danusaha untuk identifikasi kepentingan orang yang loyal terhadap objek-objek tersebut. Komitmen yang lebih tinggi dapat mempermudah terwujudnya produktivitas yang lebih tinggi (Kreitner dan Kinicki, 2011). Hasil penelitian yang dilakukan oleh Mardianai dan Dewi (2015); dan Jazuli, et al (2017), menyimpulkn bahwa komitmen organisasi berpengaruh terhadap kinerja karyawan

\subsection{Kerangka Pemikiran}

Kepuasan kerja karyawan dan komitmen organisasi memberikan umpan balik positif terhadap perusahaan. Jika kepuasan kerja dan komitmen organisasi meningkat maka kinerja karyawan akan ikut

\section{METODE PENELITIAN}

Jenis penelitian ini menggunakan metode penelitian kuantitatif dengan pendekatan meningkat dan akan berdampak baik terhadap kinerja perusahaan.

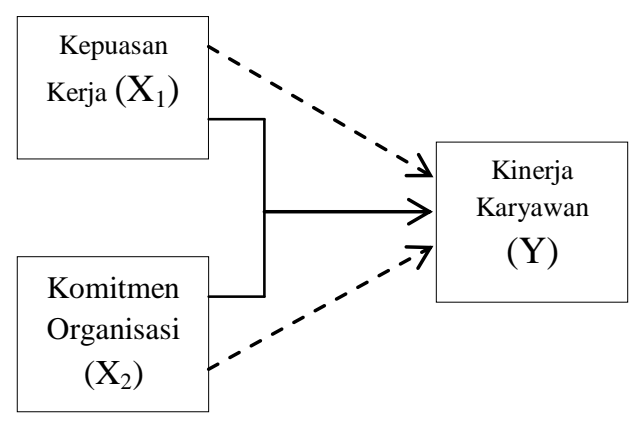

Gambar 1. Kerangka Pemikiran

\subsection{Hipotesis Penelitian}

Berdasarkan tinjauan pustaka dan kerangka pemikiran yang telah diungkap diatas, maka hipotesis dalam penelitian ini adalah:

$$
\begin{array}{rrr}
\mathrm{H}_{1} & \text { : Kepuasan } & \text { kerja dan } \\
& \text { komitmen } & \text { organisasi } \\
& \text { secara } & \text { simultan } \\
& \text { berpengaruh } & \text { terhadap } \\
& \text { kinerja karyawan. } \\
\mathrm{H}_{2} & \text { : Kepuasan } \\
& \text { berpengaruh } \\
& \text { kinerja karyawan. } \\
\mathrm{H}_{3} & \text { : } & \text { Komitmen } \\
& \text { berpengaruh } & \text { organisasi } \\
& \text { kinerja karyawan. }
\end{array}
$$

Explanatory Research. Unit analisis dalam penelitian ini bersifat individu yaitu karyawan. Tempat penelitian 
ini dilakukan di CV Lisa Jaya Mandiri Food Desa Dukuh Mencek Kecamatan Sumbersari Jember. populasi dalam penelitian ini adalah karyawan di bagian produksi cup yang berjumlah 35 orang. Metode pengampilan sampel menggunakan metode sampling jenuh/sensus. Sehingga sampel yang digunakan adalah seluruh anggota populasi yaitu sebanyak 35 karyawan.

Sumber data yang digunakan dalam penelitian ini adalah data primer yang diperoleh dari kuesioner yang diisi oleh karyawan, dan data sekunder yang diperoleh dari pihak perusahaan.

Variabel yang digunakan dalam penelitian ini meliputi variabel independen (X) yaitu kepuasan $\operatorname{kerja}\left(\mathrm{X}_{1}\right)$ dan komitmen organisasi $\left(\mathrm{X}_{2}\right)$, serta variabel dependen yaitu kinerja karyawan (Y).

Analisis data yang digunakan meliputi analisis deskriptif yaitu deskripsi responden dan analisis inferensial yaitu analisis regresi linier berganda.

\section{HASIL PENELITIAN DAN PEMBAHASAN}

\subsection{Hasil Penelitian}

Deskripsi responden didasarkan pada indentifikasi responden antar lain jenis kelamin, usia, lama bekerja dan pendidikan terakhir. Sebagian besar responden adalah perempuan sebesar 83\%, mayoritas responden berusia kurang dari 25 tahun sebanyak 57\%, 49\% responden memiliki masa kerja anatar 1-5 tahun, dan sebagian besar responden berpendidikan akhir SMA.

Data penelitian yang diperoleh kemudian dilakukan analaisis uji asumsi klasik yag meliputi uji normalitas, heteroskedastisitas dan multikolinieritas. Berdasarkan hasil uji normalitas, data penelitian berdistribusi normal. Hal ini didasarkan pada nilai Asymp. Sign lebih dari 0,05 (Ghozali,2007). Berdasarkan hasil uji heteroskedastisitas, data penelitian bebas dari heterokedastisitas. Serta berdasarkan hasil uji multikolinieritas data penelitian bebas multikolinieritas. 


\section{Analisis Koefisien Determinasi $\left(\mathbf{R}^{2}\right)$}

Koefisien determinasi digunakan untuk mengetahui seberapa besar pengaruh variabel bebas terhadap variabel terikatnya. Nilai koefisien determinasi ditentukan dengan nilai Adjusted $R$ Square sebagai mana dapat dilihat pada Tabel 1.

Berdasarkan Tabel 1 diketahui nilai Adjusted $R$ Square sebesar 0,531 atau $53,1 \%$ yang berarti bahwa sumbangan atau kontribusi dari variabel promosi penjualan terhadap minat beli sebesar 0,531. Sedangkan sisanya $46,9 \%$ mempunyai makna besarnya faktor lainnya yang tidak diterangkan pada penelitian ini.

Menurut Kasmir (2016) faktor lain yang dapat memengaruhi kinerja karyawan adalah kemampuan dan keahlian, pengetahuan, rancangan kerja, kepribadian, kepemimpinan, gaya kepemimpinan, budaya organisasi, kepuasan kerja, lingkungan kerja, loyalitas, komitmen, disiplin kerja, yang dipadukan oleh perusahaan untuk menghasilkan respon karyawan yang baik.

Tabel 4.1 Hasil Analisis Koefisien Determinasi $\left(\mathrm{R}^{2}\right)$

\begin{tabular}{|c|c|c|c|c|}
\hline Mode & R & R Square & $\begin{array}{c}\text { Adjusted R } \\
\text { Square }\end{array}$ & $\begin{array}{c}\text { Std. Error of } \\
\text { the Estimate }\end{array}$ \\
\hline $\mathbf{1}$ & 0,747 & 0,559 & 0,531 & 1,99385 \\
\hline
\end{tabular}

\section{Analisis Regresi Linier Berganda}

Berdasarkan analisis dengan menggunakan program SPSS Versi 22 diperoleh hasil regresi berganda yang ditumjukkan pada Tabel 2.

Berdasarkan Tabel 2 diperoleh persamaan analisis regresi berganda yaitu:

$\mathrm{Y}=6,813+0,523 \mathrm{X}_{1}+0,635 \mathrm{X}_{2}$
Dari persamaan model tersebut dapat diinterpretasikan sebagai berikut:

1. Konstanta (a) $=6,813$

Nilai konstanta positif sebesar 6,813, tanda positif menunjukkan hubungan yang searah. Artinya jika kepuasan kerja $\left(\mathrm{X}_{1}\right)$, komitmen organisasi $\left(\mathrm{X}_{2}\right)$ dikontrol (dianggap konstan), maka variabel kinerja karyawan (Y) akan naik. 
2. Koefisien Kepuasan Kerja $\left(X_{1}\right)$ $=0,523$

Variabel kepuasan kerja $\left(\mathrm{X}_{1}\right)$ memiliki pengaruh positif terhadap kinerja karyawan (Y) yaitu sebesar 0,523 . Tanda positif menunjukkan hubungan yang searah. Artinya, jika kepuasan kerja $\left(\mathrm{X}_{1}\right)$ naik serta komitmen organisasi $\left(\mathrm{X}_{2}\right)$ dikontrol (dianggap konstan), maka kinerja karyawan (Y) akan naik.
3. Koefisien Komitmen Organisasi $\left(X_{2}\right)=0,635$

Variabel komitmen organisasi $\left(\mathrm{X}_{2}\right)$ memiliki pengaruh positif terhadap kinerja karyawan (Y) yaitu sebesar 0,523. Tanda positif menunjukkan hubungan yang searah. Artinya, jika komitmen organisasi $\left(\mathrm{X}_{2}\right)$ naik serta kepuasan kerja $\left(\mathrm{X}_{1}\right)$ dikontrol (dianggap konstan), maka kinerja karyawan (Y) akan naik.

Tabel 2. Hasil Analisis Regresi Linier Berganda

\begin{tabular}{|l|c|c|}
\hline \multirow{2}{*}{ Model } & $\begin{array}{c}\text { Unstandardized } \\
\text { Coefficients }\end{array}$ & $\begin{array}{c}\text { Standardized } \\
\text { Coefficient }\end{array}$ \\
\cline { 2 - 3 } & B & Beta \\
\hline (Constant) & 6,813 & \\
\hline Kepuasan Kerja $\left(\mathrm{X}_{1}\right)$ & 0,523 & 0,423 \\
\hline Komitmen Organisasi $\left(\mathrm{X}_{2}\right)$ & 0,635 & 0,404 \\
\hline
\end{tabular}

\section{Uji Hipotesis Simultan (Uji F)}

Uji F dilakukan dengan membandingkan nilai $\mathrm{F}_{\text {hitung }}$ dengan $\mathrm{F}$ Tabel . Untuk degree of freedom $(\mathrm{df} 1)=\mathrm{k}-1, \quad \mathrm{df} 2=\mathrm{n}-\mathrm{k}$. Dimana $\mathrm{k}$ adalah jumlah dari keseluruhan variabel bebas dan terikat yaitu sebesar 3, dan $\mathrm{n}$ adalah jumlah sampel dalam penelitian ini yaitu sebesar 35 dan besarnya df adalah $\mathrm{df} 1=3-1=2, \mathrm{df}=35-3=32$. Pada taraf signifikan $95 \%$ atau alpha $(\alpha)$
$5 \%$ diperoleh nilai $\mathrm{F}_{\text {tabel }}=3,32$. Jika $\mathrm{F}_{\text {hitung }}>\mathrm{F}_{\text {tabel }}$ maka Ha diterima.

Berdasarkan Tabel 3 dapat dilihat bahwa nilai $F_{\text {hitung }}>F_{\text {tabel }}$, yaitu 20,258>3,32 dengan nilai signifikansi 0,00. Dengan nilai $\mathrm{F}_{\text {hitung }}$ $>\mathrm{F}_{\text {tabel }}$ dan nilai signifikannya < 0,05, hal ini berarti $\mathrm{Ha}$ diterima. Artinya kepuasan kerja dan komitmen organisasi secara bersamasama berpengaruh terhadap kinerja karyawan. 
Tabel 3. Hasil Uji F

\begin{tabular}{|c|c|c|}
\hline $\mathbf{F}_{\text {tabel }}$ & $\mathbf{F}_{\text {hitung }}$ & Sig \\
\hline 3,32 & 20,258 & 0,000 \\
\hline
\end{tabular}

\section{Uji Hipotesis Parsial (Uji t)}

Berdasarkan Tabel 4. dapat diketahui nilai $t$ dari variabel kepuasan kerja dan komitmen organisasi sebagai berikut:

1. Uji secara parsial variabel yang berpengaruh terhadap kinerja karyawan yaitu variabel kepuasan kerja yang mempunyai nilai $t_{\text {hitung }} 2,784>t_{\text {tabel }} 1,694$ dengan nilai signiifikansi sebesar $0,009<0,05$, hal ini menunjukkan bahwa kepuasan kerja berpengaruh signifikan terhadap kinerja karyawan.

2. Uji secara parsial variabel yang berpengaruh terhadap kinerja karyawan yaitu variabel komitmen organisasi yang mempunyai nilai $t_{\text {hitung }} 2,662>$ $t_{\text {tabel }} 1,694$ dengan nilai signifikansi sebesar $0,012<$ 0,05 , hal ini menunjukkan bahwa komitmen organisasi berpengaruh signifikan terhadap kinerja karyawan.

Tabel 4. Hasil Uji t

\begin{tabular}{|l|c|c|c|c|}
\hline \multicolumn{1}{|c|}{ Variabel } & $\mathbf{t}_{\text {tabel }}$ & $\mathbf{t}_{\text {hitung }}$ & Sig & Keterangan \\
\hline Kepuasan Kerja $\left(\mathrm{X}_{1}\right)$ & 1,694 & 2,784 & 0,009 & Diterima \\
\hline Komitmen Organisasi $\left(\mathrm{X}_{2}\right)$ & 1,694 & 2,662 & 0,012 & Diterima \\
\hline
\end{tabular}

\subsection{Pembahasan}

\section{Pengaruh Kepuasan Kerja dan}

Komitmen Organisasi terhadap

\section{Kinerja Karyawan}

Hasil analisis menunjukkan hipotesis $1\left(\mathrm{H}_{1}\right)$, yang menyatakan kepuasan kerja dan komitmen organisasi berpengaruh terhadap kinerja karyawan secara simultan, diterima. Penelitian ini menemukan kepuasan kerja dan komitmen organisasi berpengaruh positif signifikan terhadap kinerja karyawan secara simultan.Hal ini dapat dartikan bahwa variabel kepuasan kerja dan komitmen organisasi secara bersama-sama mampu memengaruhi kinerja karyawan. 
Secara teoritis hasil penelitian ini mendukung teori yang dikemukakan oleh Gibson et, al, dalam Sukmawati dan Gani (2014) menyatakan bahwa terdapat hubungan antara kepuasan kerja dan kinerja. Dalam teori yang dikemukakan oleh Allen and Mayer dalam Sukmawati dan Gani (2014) menyatakan bahwa dengan komitmen organisasi yang tinggi dapat memperkuat atau meningkatkan kinerja karyawan. Secara empirisi hasil penelitian ini selaras dengan hasil penelitian yang telah dilakukan oleh Mardiani dan Dewi (2015); Novita, et al (2016); Jazuli, et al (2016) yang hasil penelitiannya menemukan bahwa kepuasan kerja dan komitmen organisasi berpengaruh positif dan signifikan terhadap kinerja karyawan.

\section{Pengaruh Kepuasan Kerja terhadap Kinerja Karyawan}

Hasil analisis penelitian menunjukkan hipotesis 2, yang menyatakan kepuasan kerja berpengaruh terhadap kinerja karyawan, diterima. Penelitian ini menemukan bahwa kepuasan kerja berpengaruh positif dan signifikan terhadap kinerja karyawan. Hal ini dapat diartikan bahwa faktor-faktor kepuasan kinerja mampu memengaruhi kinerja karyawan.

Secara teoritis penelitian ini mendukung teori yang dikemukakan oleh Robbins dan Judge (2012), yang menyatakan bahwa seseorang dengan tingkat kepuasan kerja yang tinggi memiliki perasaan-perasaan positif tentang pekerjaan. Sehingga dapat dikatakan karyawan yang memiliki rasa kepuasan terhadap pekerjaan cenderung akan berkinerja lebih baik. Robbins dan Judge (2012) juga menyatakan bahwa terdapat korelasi antara kepuasan kerja dan kinerja karyawan yang cukup kuat. Dessler (2009) yang menyatakan bahwa kepuasan kerja antara lain mempunyai peran untuk mencapai produktivitas dan kualitas standar yang lebih baik, menghindari terjadinya kemungkinan membangun kekuatan kerja yang lebih stabil, seta penggunaan sumber daya manusia yang lebih efisien. Secara empiris hasil penelitian ini mendukung penelitian yang telah dilakukan oleh 
Pramitha (2012); Risqi, et, al (2015); Jazuli, et, al (2017) yang menyatakan bahwa kepuasan kerja berpengaruh secara simultan terhadap kinerja karyawan.

\section{Pengaruh Komitmen Organisasi terhadap Kinerja Karyawan}

Hasil analisis penelitian menunjukkan hipotesis 3, yang menyatakan komitmen organisasi berpengaruh terhadap kinerja karyawan, diterima. Penelitian ini menemukan bahwa komitmen organisasi berpengaruh positif dan signifikan terhadap kinerja karyawan. Hal ini dapat diartikan bahwa faktor-faktor komitmen organisasi mampu memengaruhi kinerja karyawan.

Secara teoritis hasil penelitian ini mendukung teori yang

\section{KESIMPULAN DAN SARAN}

\subsection{Kesimpulan}

Berdasarkan rumusan masalah, tujuan penelitian dan hasil analisis, maka dapat diambil kesimpulan sebagai berikut:

$\begin{array}{ccc}\text { 1. Koefisien determinasi } & \left(\mathrm{R}^{2}\right) \\ \text { dinyatakan } & \text { dengan nilai }\end{array}$ dikemukakan oleh Luthans (2006), yang menerangkan bahwa komitmen organisasi merupakan keinginan kuat untuk tetap sebagai anggota organisasi, keinginan untuk berusaha keras sesuai keinginan organisasi, keyakinan tertentu, dan penerimaan nilai dan tujuan organisasi. Komitmen yang lebih tinggi dapat mempermudah terwujudnya produktivitas yang lebih tinggi (Kreitner dan Kinicki, 2011). Secara empiris hasil penelitian ini selaras dengan penelitian yang dilakukan oleh Mardiani dan Dewi (2015) ; Novita, et al (2016); Jazuli, et al (2016), hasil penelitin mereka menunjukkan bahwa komitmen organisasi berpengarug signifikan terhadap kinerja karyawan.

Adjusted R Square adalah 0,531 atau 53,1\%. Artinya besar pengaruh kepuasan kerja dan komitmen organisasi terhadap kinerja karyawan sebesar 0,531. Sisanya sebesar $46,9 \%$ mempunyai makna 
besarnya faktor lainnya yang tidak diterangkan pada penelitian ini. Menurut Kasmir (2016:189-193) faktor lain yang dapat memengaruhi kinerja karyawan adalah kemampuan dan keahlian, pengetahuan, rancangan kerja, kepribadian, kepemimpinan, gaya kepemimpinan, budaya organisasi, kepuasan kerja, lingkungan kerja, loyalitas, komitmen, disiplin kerja, yang dipadukan oleh perusahaan untuk menghasilkan respon karyawan yang baik.

2. Regresi berganda dengan persamaan $\mathrm{Y}=6,813+0,523$ $\mathrm{X}_{1}+0,635 \mathrm{X}_{2}$ artinya tanpa dipengaruhi apapun maka kinerja karyawan mempunyai nilai konstanta positif sebesar 6,813. Variabel kepuasan kerja memiliki pengaruh positif terhadap kinerja karyawan dengan nilai 0,523 artinya jika kepuasan kerja tinggi maka kinerja karyawan tinggi. Variabel komitmen organisasi memiliki pengaruh positif terhadap kinerja karyawan dengan nilai 0,635 artinya jika komitmen organisasi tinggi maka kinerja karyawan tinggi.

3. Hasil uji hipotesis simultan (uji F) memiliki nilai $F_{\text {hitung }}$ $(20,258)>F_{\text {tabel, }}(3,32)$ dan nilai signifikansi sebesar 0,000 lebih kecil dari 0,05 , artinya secara simultan kepuasan kerja dan komitmen organisasi berpengaruh terhadap kinerja karyawan.

4. Hasil uji hipotesis parsial kepuasan kerja terhadap kinerja karyawan mempunyai nilai $\mathrm{t}_{\text {hitung }} 2,784>\mathrm{t}_{\text {tabel }}$ 1,694 dengan nilai signifikansi sebesar 0,009 $<0,05$, hal ini menunjukkan bahwa kepuasan kerja berpengaruh signifikan terhadap kinerja karyawan.

5. Hasil uji hipotesis parsial komitmen kerja terhadap kinerja karyawan mempunyai nilai nilai $t_{\text {hitung }} 2,662>t_{\text {tabel }}$ 1,694 dengan nilai signifikansi sebesar $0,012<0,05$, hal ini menunjukkan bahwa komitmen organisasi berpengaruh signifikan terhadap kinerja karyawan. 


\subsection{Saran}

1. Bagi perusahaan diharapkan untuk lebih memperhatikan langkah-langkah peningkatan kinerja agar karyawan dapat mencapai target yang telah ditentukan oleh perusahaan.

2. Bagi peneliti selanjutnya diharapkan dapat melakukan penelitian lanjutan untuk mengetahui faktor-faktor lain yang memengaruhi kinerja karyawan. Hal ini dikarenakan dari hasil penelitian ini

\section{DAFTAR PUSTAKA}

Bangun, Wilson. 2012. Manajemen Sumber Daya Manusia. Jakarta: Erlangga.

Dharma, Agus. 2003. Manajemen Supervisi: (Petunjuk Praktis bagi Para Supervisor). Ed Revisi., Cet 5. Jakarta: PT Raja Grafindo Persada.

Kreitner, Robert dan Angelo Kinicki. 2011. Perilaku Organisasi. Jakarta: Salemba Empat.

Kuswadi. 2004. Cara Mengukur Kepuasan Karyawan. Jakarta: PT Elex Media Komputindo.

Mathis, R.L. \& J.H. Jackson. 2006. Human Resource Management: Manajemen Sumber Daya Manusia. Terjemahan Dian Angelia. Jakarta: Salemba Empat.

Robbins, P.Stephen dan Mary Coulter. 2008. Manajemen. kontribusi faktor kepuasan kerja dan komitmen organisasi hanya sebesar 53,1\%, sehingga perlu diteliti faktor-faktor lain yang berkontribusi lebih besar dalam memengaruhi kinerja karyawan.

Bagi peneliti selanjutnya sebaiknya apabila ingin mengukur kinerja karyawan kuesioner tidak diberikan kepada karyawan yang bersangkutan karena jawaban bisa saja menjadi bias.

Jakarta: PT. INDEKS Kelompok Gramedia.

Robbins, P.Stephen dan Timothy A. Judge. 2012. Perilaku Organisasi. Jakarta: Salemba Empat.

Sinambela, Litjan Poltak. 2018. Manajemen Sumber Daya Manusia. Jakarta: PT. Bumi Aksara.

Apriliana, S. Hamid, D. dan Hakam M.S. 2013. Pengaruh Motivasi dan Komitmen Organisasional Terhadap Kinerja Karyawan (Studi pada PT. Bentara Sinergies Multifinance). Jurnal Administrasi Bisnis (JAB) Vol 1. No1.

Jazuli, hamim., Djamhur, Hamid., dan Mukzam, Muhammad Djudi. 2017. Pengaruh kepuasan kerja dan komitmen 
organisasional Terhadap kinerja karyawan (Studi pada karyawan tetap bagian jahit di PT. Pei hai International Wiratama Indonesia). Jurnal Administrasi Bisnis (JAB)|Vol. 42 No.1. Hal :1-7.

Mardiani, Any dan Dewi, Maya Sari. 2015. Pengaruh Kepuasan Kerja Dan Komitmen Organisasional Terhadap Kinerja Pegawai Bank Kalsel. Jurnal Wawasan Manajemen, Vol. 3, Nomor 3.

Novita, Bambang Swasto dan Ika Ruhana. 2016. Pengaruh Kepuasan Kerja dan Komitmen Organisasional terhadap Kinerja Karyawan Studi pada PT. Telekomunikasi Indonesia Tbk Witel Jatim Selatan Malang. Jurnal Administrasi Bisnis. Vol. 34 No. 1.

Paramitha. 2012. Pengaruh Kepuasan Kerja Terhadap Komitmen Organisasional Dan Kinerja Karyawan Koperasi Krama Bali. Jurnal Fakultas Ekonomi.

Sukmawati dan Gani, Nurjaya. 2014. Pengaruh Kecerdasan Emosional, Kepuasan Kerja, dan Komitmen Organisasi Terhadap Kinerja Karyawan Pada Kopersasi Karyawan PT. Telkom Siporennu Makassar. Jurnal Manajemen dan Akuntansi, Volume 3, Nomor 3 , hal 15. 